\title{
SAID'S ORIENTALISM: \\ EUROPEAN SCHOLARSHIP AS A WAY OF REALIZING AND JUSTIFYING ORIENTAL PROJECTS
}

\author{
Mustafa KARA ${ }^{1}$
}

\begin{abstract}
Orientalism has been a highly controversial subject matter which was triggered centuries ago. Various methods have been applied by the Westerners in order to explore and invade the exotic nature of the Orient so as to conquer it and benefit from all aspects of the virgin lands. European scholars and European scholarship have performed the biggest portion of this process since the more the Occident knew about the Orient, the more power and authority they exerted on the Orient and the Oriental. This, on the whole, helped the Occident describe and shape the Orient and the Oriental in accordance with the required policies in an unending time-scope since their policies and ambitions kept changing over time. Edward W. Said's invaluable work, Orientalism, made a great contribution to the area and it also provided essential answers to the question how the Europeans succeeded in encapsulating the Oriental world in colonized nations and cultures by way of their studies and scholarships. This study, therefore, endeavours to highlight Said's observations on the European scholars and scholarships as ways of imperialist impositions on the Orient as well as Westerners' justification and realization of their projects on the Oriental world.
\end{abstract}

Keywords: Orientalism, European scholarship, Occidentalism, cultural imperialism, Edward W. Said.

Kara, Mustafa. "Said's Orientalism: European Scholarship as a Way of Realizing and Justifying Oriental Projects”. idil 6.39 (2017): 3021 - 3033.

Kara, M. (2017) Said's Orientalism: European Scholarship as a Way of Realizing and Justifying Oriental Projects. idil, 6 (39), s.3021 - 3033

\footnotetext{
${ }^{1}$ Okutman, Çukurova Üniversitesi, Yabancı Diller Yüks ekokulu, mustafakara(at)live.com.
} 


\title{
SAID'IN ŞARKIYATÇILIK ADLI ESERI: ŞARK ILE ILGILI PROJELERI GERÇEKLETIRME VE MEŞRULAŞTIRMA YÖNTEMI OLARAK BATI BILLIMI
}

\author{
$\ddot{O} \mathbf{z}$
}

\begin{abstract}
Şarkiyatçılık yüzyıllar öncesinde tetiklenen, tartışmaya bir hayli açık bir alandır. Şark'1 fethetmek ve bakir toprakların nimetlerinden faydalanmak için onun egzotik doğasını keşfetmek ve sonunda işgal etmek adına Batı tarafından çeşitli birçok yöntem uygulanmıştır. Avrupalı alimler ve Batı ilmi bu sürecin en büyük bölümünü oluşturmaktadır zira Batılılar Şark ile ilgili ne kadar çok bilgi edindilerse, Şark üzerinde o kadar çok güç ve otorite sahibi oldular. Temelde bu, Batı'nın Şark'ı bitmek bilmez bir zaman çizgisinde ve her dönemin kendine has politikalarına göre tanımlamasına ve şekillendirmesine katkı sağlamıştır, çünkü Batı'nın her dönemde Şark ile ilgili politikaları değişkenlik göstermiştir. Edward W. Said'in oldukça kıymetli olan Şarkiyatçılık adlı eseri ise alana epey hatırı sayılır bir katkı sağlamış ve aynı zamanda Batılıların Şark dünyasını çeşitli çalışmalar ve ilim yoluyla nasıl sömürgeleştirilmiş uluslar ve kültürler haline getirebildiği sorusuna esaslı cevaplar sağlamıştır. Bu nedenle bu çalışma, Said'in Batılı alimler ve ilimlerin Şark üzerindeki emperyalist uygulamalar ile ilgili gözlemlerini ön plana çıkarmayı ve bu uygulamaların Batılıların Şark üzerindeki projelerinin meşrulaştırılması ve gerçekleştirilmesi için nasıl birer yöntem olarak kullanıldı̆̆ını ortaya koymayı hedeflemektedir.
\end{abstract}

Anahtar Kelimeler: Şarkiyatçılık, Batı ilmi, Batıcılık, kültürel emperyalizm, Edward W. Said. 
Science is a socially constituted discourse whose results are linked to a culture's economic, political, and ideological practices. We will never achieve an alternative, critical science until we discard the myths of scientific neutrality and the separation of science and ideology (Aronowitz, 1988: 519).

\section{INTRODUCTION}

Orientalism, as a subject matter very difficult to define, has been a controversial and a problematic phenomenon for centuries. The reason why it is challenging to put Orientalism on a definite ground is the fact that each scholar, be it a politician, an author or any other practitioner of a specific scholarship, abuses Orientalism as well as the Orient in accordance with his/her necessity. Furthermore, what makes it even more problematic is the fact that most of the professionals mentioned above use and abuse representations of the Orient rather than the truthful and down-to-earth pictures or sketches thereof. In other words, the Orient is created (orientalised in Said's words) by scholars in such a way that it turns out to be one of the most outstanding and profitable tools, which, accordingly, serves to their plans and projects about the Orient. The use of representations of the Orient, thus, provides a sort of authority, which, in the end, turns out to be one of the most prominent instruments for making the whole world, not leaving the Orient aside, believe in the orientalised Orient. This authority, moreover, is sustained by the relationship between power and knowledge. The more the scholars know about the Orient, the more authoritative and stronger they become, which, in turn, lets them shape and rule over the Orient. As such is the case, Edward Said's invaluable work, Orientalism, is highly significant since it delineates and unveils the Orientalist projects by unmasking the authority which stems from the European scholarships. For this reason, the European scholarships, for sure, turn out to be constructed and re-constructed systems, manipulating the Orient and the Oriental according to what necessitates. In light of these arguments, then, this article aims to evince the idea that instead of their experimental knowledge, most of the European scholars have shown a great effort to apply their learned knowledge on the Orient in order to realize and justify their projects more easily. Besides, racist and degrading attributions to the Orient and the Oriental, stemming from the relationship between power and knowledge as well as the authoritative voice of the Occident, will be discussed in detail.

\section{EUROPEAN SCHOLARSHIP AS A WAY OF REALIZING AND JUSTIFYING ORIENTAL PROJECTS}

It is useful to sketch Said's understanding of Orientalism in the academic sense in order to grasp a better comprehension of what scholars do. Assuming that Orientalism is not as mettlesome as before, Said proposes that anyone who writes 
about, teaches or researches the Orient becomes an Orientalist and what s/he does turns out to be Orientalism (2003: 2). In other words, Orientalism is defined as "a style of thought based upon an ontological and epistemological distinction made between 'the Orient' and (most of the time) 'the Occident' (Said, 2003: 2). This distinction, furthermore, is supplied by the knowledge that the scholars provide, which, accordingly, sets out the ties between power and knowledge since both knowledge and power are essential in establishing a discourse, which, in turn, patronizes the societies and cultures under it as in the case of Napoleon's invasion of Egypt which will also be discussed in this article. The chain of knowledge, power, authority and discourse, therefore, makes Orientalism "as the corporate institution for dealing with the Orient - dealing with it by making statements about it, authorizing views of it, describing it, by teaching it, settling it, ruling over it" (Said, 2003: 3). This is how Western consciousness has been built up; the scholars keep creating information about the Orient and the Oriental by which they can easily manage the perceptions of the Western minds. In addition, as Mansfield puts forth, "[a] more complex problem is that the average educated westerner is unaware that he suffers from prejudice towards the Arabs" (1980: 490). This, however, is not the only process of perception management, for if the conditions or the necessities about the Orient change, the scholars re-create and re-construct the information at hand. Considering this, therefore, authority is "formed, irradiated, disseminated; it is instrumental, it is persuasive; has status, it establishes canons of taste and value; it is virtually indistinguishable from certain ideas it dignifies as true, and from traditions, perceptions, and judgments it forms, transmits, reproduces" (Said, 2003: 19 - 20). The authority the Westerner holds at hand, thus, helps them lead the process of stereotyping and generalizing in a considerably well-balanced manner.

\begin{abstract}
Hence, the deep-rooted collective image in western mid about Arabs and their culture and history has been largely relying on the representation which the orientalists provided throughout the years. The dependence on this projection is mainly because of the failure of Arabs themselves to display any other alternative on the one hand, and their failure to present themselves and their culture in the shape they think is reflecting the truth on the other hand. Simultaneously, modern intellectual Arabs failed to display their history and culture in an objective manner. Ultimately, they found themselves part of two extreme groups, one that is passionately attached to the western culture, and advocates its way of life, while the other is anti-western, and aggressively rejects its fundamentals (Ramdane and Souad, 2011: 161).
\end{abstract}

It is the authority that helps Arthur James Balfour, a long-time member of the English parliament, speak to the other members by objectifying the Orient and the Oriental in accordance with his taste. This authority, moreover, is formulated and sustained by such scholars as "Chaucer and Mandeville, ... Shakespeare, Dryden, 
Pope, and Byron. It designated Asia or the East, geographically, morally, culturally" (Said, 2003: 31). Sir John Mandeville, for instance, was a dubious travel writer and he prescribed his observations in The Travels of Sir John Mandeville in the midfourteenth century while he was going to Jerusalem, the Holy Land, by passing through many countries such as Turkey, Armenia, Cyprus, Syria, Egypt, and so on. By doing so, Mandeville sketched both Christianity and Islam in addition to prominent Christians and a detailed portrait of Saracens he encountered during his travels. According to Mandeville, Saracens "have many good articles of our [Christian] faith, albeit that they have no perfect law and faith as Christian men have" (2013: 92). This, for instance, is one of the reasons why Christians adhered the title of the true religion to Christianity and also why they aimed to convert all infidels in order to get back the Holy Land, Jerusalem.

To the average and perhaps even above average educated westerners,
Islam appears as a fanatic, bloodthirsty, reactionary, xenophobic, and
largely destructive force. The obvious present-day poverty and
backwardness of most Islamic countries (due to a variety of causes
which I cannot go into now) are all too easily equated with Islam itself.
The contribution of the Arab Islamic world to western civilization
through its preservation of the Graeco-Roman heritage during the Dark
Ages is usually underestimated (Mansfield, 1980: 495).

Therefore, it is possible to grasp the idea that by abusing their predecessors' success in establishing the necessary authority through their great efforts in many scholarship areas, the Occidental have been rather influential in identifying and objectifying, valuing and devaluing, glorifying and vilifying the Orient and the Oriental. Turner, too, puts forth the idea that "Orientalism is a discourse which represents the exotic, erotic, strange Orient as a comprehensible, intelligible phenomenon within a network of categories, tables and concepts by which the Orient is simultaneously defined and controlled. To know is to subordinate" (2003: 21). The Orient is whatever the Occident designs and depicts. The relationship between power and knowledge, then, is rather significant for fixing the Occidental projects on the Oriental territories, for Balfour argues as follows:

We know the civilization of Egypt better than we know the civilization of any other country. We know it further back; we know it more intimately; we know more about it. It goes far beyond the petty span of the history of our race, which is lost in the prehistoric period at a time when the Egyptian civilization has already passed its prime (Said, 2003: 32).

Apparently, the authoritative and patronizing mood of Balfour's speech is directly - but not surprisingly - related to power, which stems from the knowledge about Egypt and the Egyptians. Due to their never-ending studies about the Oriental 
country, Balfour and his race are completely in control of what the Egyptians are and are not capable of doing, their ways of life, their beliefs, their religious practices, and so on. In short, the British are aware of all cultural, moral, and geographical information owing to the European scholars and scholarship. They know the Egyptians. "To have such knowledge of such a thing is to dominate it, to have authority over it. And authority here means for 'us' to deny autonomy to 'it' ... since we know it and it exists, in a sense, as we know it" (Said, 2003: 32). By means of authority, thus, Balfour finds ways to justify their projects on Egypt due to their lack of self-government and their so-called barbarian civilization. It is not surprising to find this justification in Europe since the European scholars formulated and created the Oriental discourse well enough to save them from their savage conditions. As Lockman also argues,

\begin{abstract}
some European scholars, writers and others appropriated certain images and notions about the East and Islam from what they had come to perceive as Europe's distinctive past, refashioned them in keeping with their own contemporary concerns, and propagated them as relevant for their own time. It is this process of selective borrowing and creative recycling, which goes on even today, that makes delving into early images and attitudes useful for understanding how Islam and the Middle East would come to be understood and portrayed even in the modern era (2010: 8 - 9).
\end{abstract}

The case, however, is not as pure as saving a race from their primitiveness. On the contrary, the European have great ideas over the Oriental country, which will return to the Occident with great profits and opportunities. Hence, it is prominent and essential to find ways of excuses in order to invade and make the colonised countries believe that they are in need of external assistance. After all, Balfour and his race "are in Egypt not merely for the sake of the Egyptians, though [they] are there for their [Egyptians'] sake; [they] are there also for the sake of Europe at large" (Said, 2003: 33). In other words, Balfour employs the teachings of the European scholars, teachers, missionaries, businessmen and soldiers in such a professional way that he prepares the invasion of Egypt smoothly and delicately. He points out the notion that Egypt's invasion is inevitable and it is for the welfare of everyone involved in this occupation.

As the agent and consul-general in Egypt, Cromer is both an opportunist of European scholarship and a source of it, for he stayed in Egypt for a very long time, which, consequently, gave him the chance to observe, experience, and learn about the Egyptian policies, culture, economics, and so on. Through his observations, Cromer identifies the Oriental - not specifically the Egyptians but all people outside the Western countries - as "subject races" (Said, 2003: 36). Because of the power and discourse they have at hand, Europeans keep identifying the Orient according to their 
necessities again. This, on the whole, is another rehearsal for justifying the invasion of Egypt as well as forming a basis for the occupation. In parallel with Balfour's ideas over Egypt, Cromer infuses that:

\begin{abstract}
[t]he mind of the Oriental ... is eminently wanting in symmetry. His reasoning is of the most slipshod description. Although the ancient Arabs acquired in a somewhat higher degree the science of dialectics, their descendants are singularly deficient in the logical faculty. They are often incapable of drawing the most obvious conclusions from any simple premises of which they may admit the truth. Endeavour to elicit a plain statement of facts from an ordinary Egyptian. His explanation will generally be lengthy; and wanting in lucidity. He will probably contradict himself half-a-dozen times before he has finished his story. He will often break down under the mildest process of crossexamination (Said, 2003: 38).
\end{abstract}

Cromer's long extract from his own work, Modern Egypt, sketches the Oriental as a primitive and illogical set of people who cannot even understand the very essences of facts, are incapable of commenting on simple issues due to their lack of cultivation and mental faculties, who, moreover, are in need of help in order to get rid of the quasi-mud of the Orient. Cromer, thus, both reflects the Western Orientalist ideas and provides new notions to the Orientalist scholarship so that they can be applied to form another power and authority when it is necessary. Although it is obvious that Cromer was one of the close observers of the Orient, it is still problematic and chaotic that most of the scholars referred to the other scholars from various periods in order to be more credible and persuasive. What makes it chaotic is that the Orient is destined to be represented by the Occident in many ways and forms, most of which are not even in truthful ways.

\begin{abstract}
The orientalist discourse was consequently a remarkably persistent framework of analysis which, expressed through theology, literature, philosophy and sociology, not only an imperial relationship but actually constituted a field of political power. Orientalism created a typology of characters, organized around the contrast between the rational Westerner and the lazy Oriental. The task of orientalism was to reduce the endless complexity of the East into a definite order of types, characters and constitutions. The chrestomathy, representing the exotic Orient in a systematic table of accessible information, was thus a typical cultural product of occidental dominance. (Turner, 2003: 21).
\end{abstract}

Lacking authenticity and methodological accuracy, most of the scholars, who did not even experience the life in Egypt or in any other Oriental country, helped the canonical establishment of various discourses in order to exert power on the known territories and cultures. After all, as is proposed by Said, too: 


\begin{abstract}
[there was] a growing systematic knowledge in Europe about the Orient, knowledge reinforced by the colonial encounter as well as by the widespread interest in the alien and the unusual, exploited by the developing sciences of ethnology, comparative anatomy, philology, and history; furthermore, this systematic knowledge was added a sizeable body of literature produced by novelists, poets, translators, and gifted travellers $(39-40)$.
\end{abstract}

All these research areas are assistive in the Occident's projects on the Orient, for they are parts of the dominant discourses of the time. It is the unawareness that encapsulates the Orientals within the body of knowledge, thereby submitting to the academic, political, cultural, moral, and religious impositions of the West. Recalling the relationship between power and knowledge, it is observable that the more the Occidentals invest on scholarship, the more conscious and strong they get whereas the more the Orient's unawareness grows, the less effective they are in resisting against the impositions of the West. This is how, then, "the sense of Western power over the Orient is taken for granted as having the status of scientific truth" (Said, 2003: 46).

Underlining the idea that the West has started and led a very successful mission of cultural imperialism with all its weapons through science, Bishop explicitly points out how mathematics was shaped by various cultures; however, the same discipline has been monopolized by the West for a long time and it has been used as a major tool for imperialist colonialism:

\begin{abstract}
One of the greatest ironies in this whole field is that several different cultures and societies have contributed to the development of what is called western mathematics: the Egyptians, the Chinese, the Indians, the Arabs, the Greeks, as well as the western Europeans. Yet when western cultural imperialism imposed its version of mathematics on the colonised societies, it was scarcely recognisable as anything to which these societies might have contributed (Bishop, 1990: 61).
\end{abstract}

In parallel with the unawareness of the Orientals mentioned above and the cunning nature of the Occidentals, this is exactly what is on stage for centuries. As well as erasing the Oriental ancestors of mathematics by way of assimilation, the West has imposed its own system of signs and equations which are embraced globally, which, in the end, provided its imperialist potency and power over the Orient and other colonized cultures and nations:

\footnotetext{
Mathematical ideas are used either as directly applicable concepts and techniques, or indirectly through science and technology, as ways to control the physical and social environment. ... So, using numbers and measurements in trade, industry, commerce and administration would all have emphasised the power and control values of mathematics. It was (and still is) so clearly useful knowledge, powerful knowledge, and it
} 
seduced the majority of peoples who came into contact with it (Bishop, 1990: 58).

Considering the enforcement of this imperialist contact with other nations, there are two options left: the first one is to omit all these cultural impositions and to float around poverty due to exclusions from various fields such as trades, production, and so on. The second choice, on the other hand, is to admit the potency and power of the West and surrender to their knowledge, thereby drifting away from the inherent and indigenous cultural heritage.

All these facts and artefacts contribute to the making of Orientalism as a learned field of study. As many institutions, faculties, and scholarships came up, Orientalism was transformed into a school of thought as well. The learned field of study, thus, rendered the Westerners to establish boundaries between themselves and the others, as they name it. Said's term, "imaginative geography" (2003: 54), therefore, is applicable to what these studies and scholarships have made so far. All scholarships, among which are history, literature, politics, economics, cultural studies, and so on, are man-made. Therefore, the geographical borders are imaginative, too, and they also help formulating binary oppositions, which supply identifications and definitions of the Orient and the Occident. Unsurprisingly, all these facts and artefacts contribute to the Western projects over the Orient since they are all used in the forming and shaping of the discourses, which, as mentioned before, provide power to the Westerner. After all, "we need not look for correspondence between the language used to depict the Orient and the Orient itself, not so much because the language is inaccurate but because it is not even trying to be accurate" (Said, 2003: 71). As such is the problem, the binary oppositions, the imaginative geographical borders, and everything related to shaping a discourse that the Westerners formulate turn out to be arbitrary and sneaky, for all these are components of a wheel, which endeavour to operate people's minds in order to realize and justify Oriental projects. An anecdote of a Kpelle student's case is highly significant for understanding the Westerner's sense of the logical and the irrational:

\footnotetext{
A Kpelle college student accepted all the following statements: (1) the Bible is literally true, thus all living things were created in the six days described in Genesis; (2) the Bible is a book like other books, written by relatively primitive peoples over a long period of time, and contains contradiction and error; (3) all living things have gradually evolved over millions of years from primitive matter; (4) a "spirit" tree in a nearby village had been cut down, had put itself back together, and had grown to full size again in one day. He had learned these statements from his Fundamentalist pastor, his college Bible course, his college zoology course, and the still pervasive animist culture. He accepted all, because
} 
all were sanctioned by authorities to which he feels he must pay respect (Gay and Cole, 1967: 35).

The Occidental way of colonization, then, does not function only on the Oriental territories, but they also work on the minds, for, if the anecdote above were about a Western student admitting some sort of Islamic belief, s/he would definitely be reported to be poisoned with all irrationalities of Islam whereas a non-Westerner is sanctioned for embracing Christian ideals and earns the right of education in the Westerner's college.

Sir William Jones, as another exemplification of the Occidental scholar, was rather influential and supportive with his personal work, Objects of Enquiry During My Residence in Asia, for the other scholars and for those Westerners who aimed to invade the Orient. As mentioned before, knowing brings about power and one can easily possess the known through that power. This is why Jones investigates nearly all aspects of life in India, for "it is [his] ambition to know India better than any other European ever knew it" (Said, 2003: 78). His ambition of knowing India better than any other European is surely correlated with the goal of colonizing India. Let alone the relationship between power and knowledge, it is highly important to know one's enemy in order to beat him in an irreversible way. This is why Jones does a lot of surveys, among which are as follows:

\begin{abstract}
the Laws of Hindus and Mohammedans, Modern Politics and Geography of Hindustan, Best Mode of Governing Bengal, Arithmetic and Geometry, and Mixed Sciences of the Asiaticks, Medicine, Chemistry, Surgery, and Anatomy of the Indians, Natural Productions of India, Poetry, Rhetoric and Morality of Asia, Music of the Eastern Nations, Trade, Manufacture, Agriculture, and Commerce of India (Said, 2003: 78).
\end{abstract}

Mastering on all these strategical topics, it is considerably easy for a nation to grasp the core points of the ways of a race. Looking back to history of World War II, the expectance that Germany would override Russia's soldiers was really high; nevertheless, Hitler's lack of geographical information about Russia, for instance, made him lose the war due to the intolerable and irresistible cold weather since most of the soldiers died freezing while some of the remaining soldiers were lost in the vast country. Hitler's miscalculation, thus, made him the losing side of the war though he had the most precious and heavy weapons of the time. Considering this, Jones' attempt of an intense survey of India justifies the ends of his efforts due to his willingness in his country's ruling over India and making it another colony.

The Orient has always been an attraction for the European due to its geopolitical significance for trade ways; therefore, most of the times it is Britain and France who showed great efforts to possess these significant lands. The country succeeding in colonizing the Orient would be considerably privileged and strong in terms of politics and economics as in the case of Britain, who "emerged practical economic and political control of [India]" (Said, 2003: 76) after various wars with 
France. In order to stop Britain's gradually growing and threatening condition, Napoleon, who could be listed among the smartest military leaders for his intellectual and political strength, chose "to harass Britain's Oriental empire by first intercepting its Islamic throughway, Egypt" (Said, 2003: 76), for "Egypt was the focal point of the relationships between Africa and Asia, between Europe and the East, between memory and actuality" (Said, 2003: 84). What makes Napoleon such a smart military man is not very different from that of Jones's since Napoleon, too, benefits from scholarship and tries to find out and learn every single detail about the Egyptians' ways of life such as their Islamic practices, policies, Egypt's geographical properties, and so on. His preparations, therefore, are of great significance in order to comprehend the prominent role of European scholarship behind his success. First of all, he founded the Institut d'Ègypte, which enabled him to "build a sort of living archive for the expedition, in the form of studies conducted on all topics by the members" (Said, 2003: 81) of the institution. The relationship between power and knowledge is again on the stage of the Oriental history, for Napoleon's struggles are totally within the frames of authority through empirical and practical knowledge. By this way, it would be considerably easy for Napoleon to break through the potential obstacles in Egypt. The biggest obstacle he would face was definitely his religious status as a non-Muslim in a Muslim country, which, in turn, would make him and his nation the biggest enemy in the eyes of the Egyptians. This is why he struggled a lot to persuade Egyptians that "nous sommes les vrais musulmans" (Said, 2003: 82), which means that Napoleon and his race are the true Muslims. This, however, could not be possible via a verbal articulation; Napoleon was assisted by many religious figures of Islam in Egypt. Furthermore, all his soldiers accompanying him acted like Egyptians in terms of their clothing, Islamic practices, and so on. Thus, erasing the necessity for a military action, Description de l' Ègypte was comprehensively useful for Napoleon. He invaded a vast country without even firing a bullet, which should be highly praised, for it calls for the significance of the role of European scholarship in realizing the projects within the Oriental frames. After all, as Said also suggests it, "the Orient needed first to be known, then invaded and possessed, then re-created by scholars, soldiers and judges, who disinterred forgotten languages, histories, races, and cultures in order to posit them" (2003: 92).

\section{CONCLUSION}

The Occident has been highly interested in the Orient for a long period of time. In order to achieve and justify their projects over the Orient, the Westerners conducted a wide range of studies. These studies were not only for formulating discourses, which, in turn, provided authority and power for the Occident, but also for learning about the Orient so that all the barriers before the occupiers could easily be removed. Apart from that, the European scholarships provided the notions of power political, 
power intellectual, power moral, and power cultural, as Said poses them, through which the Occident identified the Orient and knew about every possible way of their lives. As a result of these types of power, the Occident could easily maintain their projects on the Orient via creating and re-creating discourses as well as producing and re-producing the Orient itself. This is why Orientalism is "an elaboration not only of a basic geographical distinction ... but also of a whole series of "interests"', (Said, 2003: 12). These interests, for sure, are achieved and maintained "by such means as scholarly discovery, philological reconstruction, psychological analysis, landscape and sociological description" (Said, 2003: 12). Additionally, institutionalizing Orientalism rendered the Westerner stronger and stronger since they brainwashed and employed perception management via their institutions and the works produced by the scholars in these institutions. Therefore, in parallel with the notion of shaping and re-shaping the Orient and the Oriental, it is possible to conclude that "never has there been such a thing as a pure, or unconditional, Orient; similarly, never has there been a nonmaterial form of Orientalism, much less something so innocent as an 'idea' of the Orient" (Said, 2003: 22 - 23); on the contrary, "there was (and is) a linguistic Orient, a Freudian Orient, a Spenglerian Orient, a Darwinian Orient, a racist Orient - and so on" (Said, 2003: 22).

\section{BIBLIOGRAPHY}

Aronowitz, Stanley. "The Production of Scientific Knowledge: Science, Ideology, and Marxism." Marxism and the Interpretation of Culture. Eds. Cary Nelson and Lawrence Grossberg. London: MacMillan Education Ltd., 1988. 519 - 37. Print.

Bishop, Alan J. "Western Mathematics: The Secret Weapon of Cultural Imperialism." Race \& Class 32.2 (1990): 51 - 65. Print.

Gay, John, and Michael Cole. The New Mathematics and an Old Culture: A Study of Learning among the Kpelle of Liberia. Eds. Spindler, George and Louise Spindler. USA: Holt, Rinehart and Winston, Inc., 1967. Print.

Lockman, Zachary. Contending Visions of the Middle East: The History and Politics of Orientalism. New York: Cambridge University Press, 2010. Print.

Mandeville, John. The Travels of Sir John Mandeville: The Fantastic 14thCentury Account of a Journey to the East. New York: Dover Publications Inc., 2013. Print.

Mansfield, Peter. The Arabs. Penguin Books, 1980. Print. 
Said, Edward W. Orientalism. London: Penguin Books, 2003. Print.

Ramdane, Tahraoui, and Merah Souad. "Between Orientalists and Al Jazeera: Image of Arabs in the West (Comparative Inquiry)." International Journal of Humanities and Social Science 1.4 (2011): 160 - 69. Print.

Turner, Bryan S. Orientalism, Postmodernism and Globalism. London and New York: Routledge, 2003. Print. 